Vjeran K A T U N A R I Ć (Zagreb)

vjeran.katunaric@zg.t-com.hr

\title{
DRUŠTVENE PREDODŽBE, SLOJEVI VREMENA I ANTICIPACIJA U TRI POZNATA UMJETNIČKA DJELA
}

Primljeno: 7. 2. 2020.

UDK: 821.134.2.09-31Cervantes Saavedra, M.:316.75

$7: 316.75$

U prvom dijelu ovog priloga iznesena su pojmovno-teorijska polazišta s obzirom na društvene reprezentacije/predodžbe, vremensku strukturu i anticipaciju budućnosti u umjetničkim djelima. Kao prvorazredan primjer za analizu tih polazišta uzet je roman Miguela Cervantesa Don Quijote. Pojam društvenih reprezentacija (Durkheim, Moscovici, Abric) može se ilustrirati obilježjima glavnih likova u Cervantesovu romanu. Cervantesova implicitna vizija budućnosti, izuzimajući obrat na kraju romana, bliža je Sanchovoj realističnosti i pesimizmu nego Don Quijoteovu idealizmu i optimizmu. Takvo pomicanje središta društvene svijesti ima dvostruk učinak na način razumijevanja društvene zbilje. Prvo, smanjuje se komplementarnost, a povećava proturječnost između središnjeg (vizionarskog) i perifernog (iskustvenog) polja svijesti. Drugo, ta proturječnost potiče na obrtanje odnosa između uzvišenog i banalnog u ime rada slobodnog tržišta. Analizi Don Quijotea pridodane su radi usporedbe, a posebno radi uočavanja anticipacijske dimenzije, analize slika Jana van Eycka (Portret para Arnoflini) i Leonarda da Vincija (Posljednja večera). $U$ oba slučaja naznačena su obilježja nadolazećeg vremena dugog trajanja, kapitalizma. U prvom je naglašena funkcija braka kao institucije prijenosa i povećanja privatnog vlasništva u savezu između nove srednje klase u usponu i stare gornje (feudalne) klase. $U$ drugom slučaju razmotreni su dalekosežni učinci najavljenog Isusova odlaska i ispražnjavanja moralnog središta kršćanstva. Time se otvara prostor dugom prodoru i konačnoj prevlasti kapitalizma u društvu. Njegovo je moralno središte (Crkva) provizorno, u biti razapeto između iluzornog očekivanja Isusova povratka i prijetećeg narastanja totalne ekonomske moći koja ne dopušta alternativu i kao da želi zamijeniti "jedinog Boga". U Zaključku se otvara pitanje za buduća istraživanja o utjecaju sljedeće epohe, prosvjetiteljstva, na niveliranje vrijednosti u cilju znanstvenog raščaravanja svijeta, širenja centrifugalnih sila tržišta i daljnje demoralizacije društva.

Ključne riječi: umjetnička djela, Don Quijote, društvene reprezentacije, središnje i periferno polje, vremenski slojevi, anticipacija 


\section{UVOD}

Kako "stići do nepoznatog"? Rimbaud nudi pjesnika kao vidioca... I za stare Grke pjesnik i proricatelj radili su skupa... pjesnik je gledao u prošlost, a proricatelj u budućnost... Što je vidjelac vidio? To nije mogla biti slika u uobičajenom smislu - nije vidljiva stvar; ne može se biti bliže ili dalje od tog nepoznatog. Ono što je vidjelac mogao vidjeti bila je činjenica transcendencije. To je, kao što nam govori Merleau-Ponty, "transcendencija sadašnjice što zapravo omogućuje povezivanje prošlosti i budućnosti”. (Wiskus 2013: 116)

U ovom članku izložene su dvije razine analize sadržaja umjetničkog djela: analiza različitih polja društvene svijesti i analiza spoznaje različitih društvenih vremena u umjetničkom djelu, uključujući anticipaciju budućnosti. $\mathrm{U}$ renesansnom razdoblju, iz kojeg potječu analizirana djela, umjetnička spoznaja često se koristi mitsko-religijskim pretpostavkama, najčešće biblijskim, a rjeđe služi kao jednoznačno svjedočanstvo vremena. Anticipacija budućnosti kombinacija je umjetnikove transpozicije nekih mitsko-simboličkih sadržaja i intuitivnog rašľlanjivanja slojevite sadašnjosti. U mnoštvu različitih tendencija, koje se odnose na zapažena obilježja likova i situacija, umjetnik ili umjetnica prepoznaje one koje će prevagnuti nad ostalima. ${ }^{1}$

Kao prvorazredan primjer za analizu društvenih reprezentacija i dimenzija društvenog vremena uzet je roman Miguela Cervantesa Don Quijote. Radi daljnjih objašnjenja umjetničke anticipacije, svakako najsloženije spoznaje, pridodane su analize dviju slika iz ranijeg razdoblja renesanse, Portret para Arnolfini Jana van Eycka i Posljednja večera Leonarda da Vincija. ${ }^{2}$

U prvom dijelu članka iznesena su opća, pojmovno-teorijska polazišta. U drugom su prikazane neke interpretacije Don Quijotea, a napose pojmovno-teorijski okvir za analizu središnjeg i perifernog polja društvenih reprezentacija. Iako se autori potonjeg analitičkog okvira ne referiraju na Cervantesov roman, nego općenito na strukturu društvene svijesti, njihova

${ }^{1}$ Za razliku od autora koji ne vide mogućnost anticipacijske umjetnosti prije Duchampa i konceptualizma (usp. Guitierrez 2013), ovdje se oslanjamo na Simmelovo zapažanje o vremenski slojevitoj strukturi (promatrane) sadašnjosti u kojoj će jedan sloj ili proces prevladati nad ostalima i tako hegemonijski obilježiti neku "buduću sadašnjost" (vidi opširnije u Katunarić 2001). Pritom kao prvorazredan primjer uzimamo kapitalizam. Trebalo mu je nekoliko stoljeća "suživota" s feudalizmom, dakako, i iskorištavanja mogućnosti raspolaganja slabo plaćenom (u Europi) i robovskom radnom snagom (u kolonijama), a potom "suživota" s nacijom-državom da bi na koncu nadvladao sve protuteže.

${ }^{2}$ Za razliku od književnih djela slike ne omogućuju analizu sadržaja društvene svijesti likova, pa je analiza u ovom slučaju ograničena na detalje koji se tiču vremenskih dimenzija. 
analiza omogućuje pobliže razumijevanje mentaliteta i društvene relevantnosti dvaju glavnih likova romana. Treći dio članka obrađuje anticipacijsku dimenziju romana, čemu su u četvrtom dijelu pridodane analize elemenata različitih vremena i anticipacije na spomenutim slikama. Na kraju kraćeg Zaključka otvoreno je i pitanje koje može biti poticajno za srodna istraživanja, naime o ulozi (sljedeće) epohe, prosvjetiteljstva, i znanosti u niveliranju odnosa između uzvišenog i banalnog, Don Quijotea i Sancha.

\section{POJMOVNO-TEORIJSKA POLAZIŠTA}

\subsection{DRUŠTVENE REPREZENTACIJE}

Prvo polazište odnosi se na strukturu društvene svijesti koju umjetnička djela dijele sa strukturom znanstvene spoznaje, ali i zdravorazumskih shvaćanja svijeta. Taj obuhvatni fenomen nazvan je, prema klasičnom sociologu Emilu Durkheimu, društvenim reprezentacijama ili predodžbama (les representations sociales). Isti su pojam teorijski razradili socijalni psiholozi-kognitivisti, okupljeni oko Sergea Moscovicija. Pritom su razlučili dva međusobno povezana polja društvene reprezentacije, središnje i periferno, što se može primijeniti i za analizu višestrukih vremena u umjetničkom prikazu zbilje, prvenstveno u književnom djelu. U Cervantesovu romanu ti se heuristički aspekti mogu uočiti, s jedne strane, u vrijednostima i običajima ili samo uvjerenjima od jučer, koje glavni lik, Don Quijote, nastoji ovjekovječiti kao univerzalni mit. U smislu spomenute kognitivne sheme mit se nalazi u središnjem polju društvenih reprezentacija. S druge strane, ono što je današnje i svakodnevno nastoji se odvojiti i nastaviti živjeti u rijeci vremena čije događanje ne donosi bitne promjene. To je periferno polje društvenih reprezentacija, koje predstavlja Sancho Panza. On nevoljko slijedi gospodara jer ne razumije, ni aksiomatski ni pragmatični, smisao njegovih riječi i postupaka. Sancho je porijeklom seljak kojemu ni nadolazak kapitalizma nije pružio šansu za izbor. Iz tog prividnog procesa emancipacije rađa se novi apsolutist, kapital. On se, kao i stari apsolutist, prema narodu odnosi kao prema nižim dijelovima svog tijela. Novo se bogatstvo stvara i raste zahvaljujući ubrzavanju obrtanja kapitala i eksploataciji tuđeg rada. Doduše, neko vrijeme, kapital je primoran davati veće naknade za fizičko obnavljanje unajmljenih radnika (što Don Quijote Sanchu i drugima čini iz velikodušnosti); također nudi donacije za civilno društvo i niz dvosmislenih potpora s ciljem "pranja novca". No 
svoju je "velikodušnost" spreman uskratiti prvom prilikom i smjestiti višak imovine u "porezne rajeve". Također, ni novi apsolutist ne ponaša se obzirno prema ljudima i s istom se ružnom navikom okomljuje na prirodu. On je pokretač kaosa i kažnjava svoje protivnike. Uslijed slamanja demokratskog otpora nastaje poznati kontrarevolucionarni paradoks. Većina ljudi čini sve što može, od podmićivanja svim i svačim do preklinjanja radi poštede od najgore kazne. Tako se velikom gazdi omogućuje nesmetan život izvan stvarnosti. Zauzvrat, on ide dalje te još više zapostavlja svijet života i nemilice troši resurse. Istim automatizmom koji vodi u bezumlje dovodi u pitanje i vlastiti opstanak. Napokon, u dugo najavljivanom apokaliptičnom svijetu, gdje ljudi i prirodnih resursa gotovo više i nema, mogu nakratko opstati samo roboti, koji, kao i uništena priroda, nemaju obzira prema metafizičkom autoritetu. Bogu se često za pomoć obraćao Don Quijote, ali ne i Sancho, koji je zaključio da mu to ne pomaže, kao što mu ne pomaže ni klasa kojoj pripada njegov gospodar, njezina čudesna iznimka. Umjesto toga vjeruje (kao što ćemo uskoro moći iščitati) da se sreća pojavljuje toliko rijetko da se njome ne može raspolagati, baš kao ni kockarnicom. Takva međuzavisnost projekcije svemoguće vlasti i posvemašnje materijalne bijede, koja vodi u zajedničku propast (usp. Marx i Engels /1848/ 2008: 2), rezultat je sve većeg uzdizanja oligarhijske u odnosu na mnogobrojnu donju klasu. Što je veća bijeda drugih, to je veći sjaj prvih. Takvo okrunjenje kapitala ima se zahvaliti i masovnom prihvaćanju iluzije o tome da je gramzivost, poput slobodnog tržišta Adama Smitha, pokretački mehanizam za stjecanje narodnog bogatstva. Obje se iluzije, monarhijska i nagonska, lako spajaju u jedinstvenu pod kraticom TINA (There Is No Alternative): iako grozna, postojeća je stvarnost ili nepromjenjiva ili najbolja u odnosu na ostale, prošle ili suvremene, od plemenskih zajednica do suvremenih preostataka socijalizma. S takvim razumijevanjem zbilje nije se slagao Don Quijote. Nije ni Sancho, ali ju je morao prihvatiti jer nema izbora i prepušten je varljivoj sreći o kojoj ima loše mišljenje kao i o društvenoj stvarnosti. Po svemu sudeći, nije vjerovao ni u budućnost. Što o tome ima kazati umjetnik?

\subsection{UMJETNIČKA ANTICIPACIJA}

Anticipacija je kao umjetnički dar priznata u dijelu filozofijske estetike. Eklatantan je primjer Maurice Merleau-Ponty:

Ne mogu više vidjeti od cjeline prošlosti nego od cjeline budućnosti: ipak, u trenutku ostvarenja obje se pojavljuju kao da su bile ondje, u sadašnjosti, 
čitavo vrijeme. Vidovitost je na djelu... Prije nego doživljaj ovog vremena koje imamo u uobičajenom životu, jer dimenzija prošlosti koje više nema, budućnosti koje još nema te sadašnjosti koja je jedina ovdje u potpunosti mitsko vrijeme nudi dubinu u kojoj su neki događaji "s početka” neprekidno djelotvorni. (Merleau-Ponty 1968: 24)

Ontologijski najotvoreniji izričaj idealizma, spojen s dijalektičkim poimanjem povijesti, ali i s autorovom religioznošću, sadržan je u poznatoj bilješci Waltera Benjamina o slici Angelus Novus Paula Kleea. Prema Benjaminu, anđeo na slici licem je okrenut prošlosti, ali ga nešto neodoljivo tjera $\mathrm{k}$ budućnosti:

Njegovo lice okrenuto je prošlosti. Ondje gdje mi vidimo lanac događaja, on vidi jednu jedinu katastrofu koja niže ruševine jednu za drugom... On bi najradije na trenutak zastao da probudi mrtve i da složi porušeno. Ali vjetar što puše iz raja zahvatio je njegova krila tako jako da ih anđeo više ne može sklopiti. Vjetar ga neizbježno vodi u budućnost kojoj je okrenuo leđa, dok gomila ruševina pred njim raste do neba. Taj je vjetar ono što zovemo napredak. (Benjamin 1974: 6) ${ }^{3}$

Drugačije je (neo)idealističko poimanje umjetnosti Benedetta Crocea. On smatra da stvaralačka ideja umjetnika ne sadrži izvanumjetničke poruke i sumnja u moć intuicije i mogućnost anticipacije. Općenito, hjumovski odbacuje mogućnost postojanja nevidljivih veza između pojave i nekog dubljeg ili obuhvatnijeg uzroka, držeći se opisa pojavnog predmeta (i "apsolutnog historicizma") te smatrajući da je uzročnost nepouzdana teorijska konstrukcija, a može biti i laička. Za takvu konstrukciju ima niz naziva: "duhovna imaginacija i intuitivni intelekt" koji dijalektički spajaju suprotnost između "konačnog i beskonačnog”, "oblika i sadržaja", "apstraktnog i konkretnog”, "intuicije i razuma", priznajući da sâm nema nijednu od tih sposobnosti i da ne zna kako ih steći.

Međutim, Croce nije posve dosljedan u svom pozitivizmu i formalizmu niti smatra modernu potpunim raščaravanjem svijeta i rastankom od srednjovjekovnog imaginarija - kao da je renesansni autor. Tako na drugom mjestu u slikaru otkriva neobičnu sposobnost:

${ }^{3}$ Navedeni odlomak nadahnut je jednim stihom o anđelu koji bi se načas htio vratiti u smrtni život, uvrštenim u prethodnu Benjaminovu bilješku. Autor je tog stiha izraelski filozof $i$ istraživač kabalističke književnosti Gerhard (Gershom) Scholem, inače Benjaminov prijatelj (Benjamin 1974: 5). 
Slikar je slikar zbog toga što vidi ono što drugi samo osjećaju ili na trenutak pogledaju, ali ne vide. Mislimo da vidimo smiješak, ali u zbilji imamo samo nejasan dojam o tome, ne zapažamo sve tipične crte iz kojih smijeh proizlazi kao što ih zapaža slikar nakon svojih unutarnjih meditacija, što mu omogućuje da ih nanese na platno. (Croce /1902/ 2013: 12-13)

To podsjeća na njegove termine "intuitivni intelekt" i "mistična estetika", s obzirom na to da slikar ima genijalnu moć zapažanja nevidljivog. Iza tog zida pojavljuje se novi svijet koji opet zapaža jedino umjetnik. To nadilazi linearnu vremensku perspektivu. Slikarska vizija vremena podsjeća na Blakeovu viziju “četverostrukog čovjeka” i Simmelov doživljaj isprepletanja vremena u velegradskoj vrevi.

Ovaj teorijski odjeljak može se zaokružiti riječima pripovjedača (Cervantesa) o povijesti kao smislenoj crti vremena:

Ni interes ni strah, ni mržnja ni ljubav ne smije ih skrenuti sa staze vrline, kojoj je mati povijest, suparnica vremena, čuvarica djelâ i radova, svjedokinja prošlosti, primjer i učiteljica sadašnjosti, savjetnica budućnosti. (Cervantes /1605/ 2019: 68-69)

\section{ZBOGOM IDEALIZMU}

Nastavimo riječima Don Quijotea, naravno, opet autorovim, koje na sličan način ukazuju na dijalektički odnos između mita i stvarnosti, u kojem nijedna strana nije izgubljena. Naposljetku, ni djelo nije bez razloga postalo toliko slavno:

Sretna li doba i sretna li stoljeća kad se izdaju na svijet slavna moja junačka djela, vrijedna da budu salivena od mjedi, isklesana u mramoru i naslikana na slikama, da budućnosti ostane uspomena. (Cervantes /1605/2019: 27) 


\subsection{PRIVREMENI PORAZ DOBROG NAUMA}

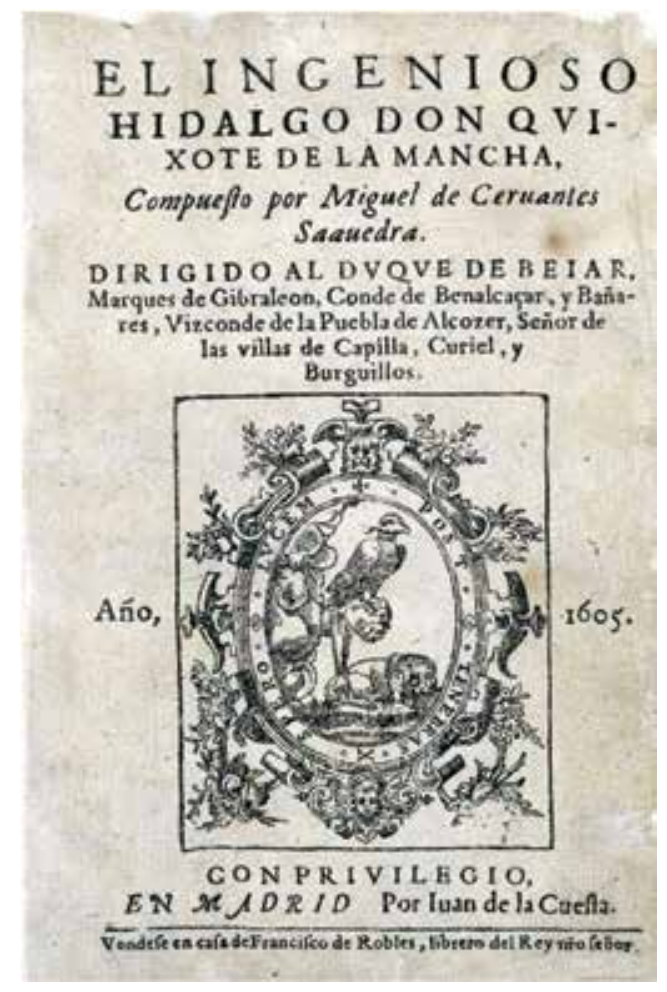

Don Quijotea moguće je razumjeti kao transpoziciju lika Isusa Krista. Cervantesov junak također je pridavao iznimnu važnost svojim riječima i djelima i uzimao ih kao primjere osobnog integriteta, ljudskog dostojanstva i misije oslobođenja, koja se smatrala viteškom vrlinom. Naposljetku je postao žrtvom vlastite težnje koju je okolina odbacila kao iluzornu i opasnu. ${ }^{4} \mathrm{~Pa}$ ipak, Cervantes je između Don Quijotea i Sancha podastro paletu drugih likova, uključujući emancipacijske. ${ }^{5}$

Sancho je samo uvjetno sličan Judi, naime nije sklon podmićivanju i prokazivanju, nego se trudi Don Quijoteu otvoriti oči da uvidi s kim ima

${ }^{4}$ To je odlika sudbine "patećih idealista" modernih religija, kako ih naziva Rebekah Marzhan (Marzhan 2012).

${ }^{5}$ Izvanredan je primjer Ana Félix, muškobanjasta djevojka čija pojava u romanu dovodi u pitanje održivost imperijalne muškosti (usp. Marchante-Aragón 2016). 
posla, da u svojim jurišima protiv nepravdi ne izgubi svaku vezu s okolinom te da sačuvaju barem svoje živote, kada već nije moguće sačuvati dostojanstvo.

U nastavku ćemo iznijeti nekoliko zapažanja o glavnim likovima relevantnih za poimanje društvenih reprezentacija. Ustvrdivši da je "središnja tema Don Quijotea fikcionalna", što nije samo njezin raison d' tre, nego i "način na koji se uvlači u život i preobražava ga", Mario Vargas Llosa zadire u jedno od ključnih ontoloških pitanja za društveno-humanističke znanosti, a to su promjenjivi odnosi između idealnog i realnog:

Zapravo, na koncu Don Quijote trijumfira; fikcija inficira istinski život i stvarnost se otvara njegovim fantazijama. Sancho Panza, koji je predstavljen kao materijalist i pragmatik, na kraju se prepušta užicima imaginarnog i, kao upravitelj Baratarije, prilagođuje se svijetu laži i iluzije. Njegov jezik, koji je na početku priče prizeman, izravan i populistički, postaje profinjen i tu i tamo jednako pretenciozan kao u njegova gospodara. (Vargas Llosa 2010: 59)

Štoviše, zaključuje da Don Quijote i Sancho Panza još uvijek jašu i cijelim svijetom prolaze kao "jedna usamljena sjena". Potonji izraz od ključne je važnosti u analizi romana stoga što su ti likovi vezani jedan uz drugog pupčanom vrpcom.

Slično je intoniran esej Myriam Yvonne Jehenson i Petera N. Dunna, koji likove vezuju uz prijelazno doba povijesti:

Don Quijote... proizvod je doba hibridnosti u kojem je uvećano iskustvo praktičnih ljudi, što je izazov znanju koje je nekoć bilo ograničeno na učenjake. Bilo je to doba u kojem je feudalizam ustupao mjesto kapitalizmu u kojem je bogatstvo trgovaca omogućilo dobivanje titula koje su nekoć bile rezervirane za aristokrate, razdoblje u kojem su shvaćanja starih bila i dovedena u pitanje i primijenjena u objašnjavanju novog i eksperimentalnog. Ta kulturna polifonija odjekuje kroz čitav Cervantesov roman. (Jehenson i Dunn 2010: 128-129)

\subsection{PESIMIZAM}

Istine moderne epohe izlaze na vidjelo polarno i pluralno. Polarno u smislu oštrog suprotstavljanja jednog lica drugom, odnosno pravde i odustajanja od njezine primjene u praksi. Tipičan je rezultat tog sudara ideje i ostvarenja sloboda (nekolicine) bez jednakosti (sviju) (liberalna varijanta) i jednakost bez slobode (varijanta realnog ili povijesnog socijalizma). U pluralnom načinu pak moderna uspostavlja izvjesnu ravnotežu s kontinuumom između 
krajnosti. Kontinuum se kao čamac na valovitom moru naginje više na jednu ili drugu stranu ili naizmjence, a znade se i prevrnuti, kao u desetljećima desnog i lijevog totalitarizma. Pa ipak, nakon nekog vremena naša dva junaka ponovo jašu zajedno, vraćajući se u nestabilnu ravnotežu. Don Quijote oličenje je etosa pravednosti, koji u modernoj epohi preuzima demokratski ustav. Sancho je pak utilitaran, ali ne baš tržišni akter. U svakom slučaju, ravnoteža ne leži na jednoj točki, nego unutar održivog intervala. Takav širokogrudni razmak u sredini isključuje krajnje licemjerje i onemogućuje shizofren raspad društvene svijesti. Istini za volju, to je više projektirano nego dostupno stanje. Društvena ravnoteža počela se urušavati već od postrevolucionarne Francuske obilježene terorom. Tek nakon Drugog svjetskog rata uspostavljena je na Zapadu liberalna demokracija s relativno kratkotrajnim društvenim konsenzusom između gornjih i donjih društvenih klasa. Ukratko, bez potrebe za iscrpnim opisom daljnje povijesti moderne demokracije, može se zaključiti da se danas, uspostavom postdemokracije (demokracije prepuštene stihiji ekonomskih tržišta) na Zapadu i usponom novog autoritarizma u drugim dijelovima svijeta obnavljaju tendencije povratka feudalizmu koji nisu prihvaćali ni Don Quijote ni Sancho. Po svemu sudeći, umjesto restauriranog feudalizma nastaje nestabilan hibrid različitih poredaka moći u kojem parlamentarna demokracija služi kao spektakularna pozornica političkih taština koje ne podnose demokraciju kao neprestano sančovsko zanovijetanje.

Stiješnjen vlastitim proturječnim obećanjima slobode i jednakosti, koja ne može ispuniti, zapadni liberalizam ponavlja sudbinu socijalizma 20. stoljeća. Obje moderne ideologije nisu starački oronule kao vitez i njegov konj u dugom hodu kroz nesklono vrijeme. Njihova je sudbina prije slična Sanchovu neuspjelom upravljanju otokom. Njega su izgurali jači sudionici koji, zapravo, nikada nisu ni otišli iz tog prostora, nego su jedva čekali čas da istjeraju i njega i njegova gospodara te da izvrgnu ruglu sve utopije jednakosti i slobode.

Možda će jednog dana stvar u ruke uzeti uporni sljedbenici tih ideala. Ljude se moglo istjerati iz raja, od Adama i Eve do Kolumbovih domorodaca, ali oni će se vratiti, poput suvremenih imigranata. Prema Jehenson i Dunnu, taj prostor želja stvorio je upravo Don Quijote:

Don Quijote preobrazio se u skladu sa svojim fikcionalnim modelom. On se udaljio od svog bivšeg života da bi stvorio nov prostor postojanja u kojem bi se njegove utopijske želje i fantazije mogle ostvariti. (Jehenson i Dunn 2010: 132) 
Istodobno, Sancho upozorava da se željena sredina ne može graditi na takvom tlu i da je idealizacija promašaj. Za njega ni selo, odakle dolazi, nije manje koruptivno od grada, a o plemstvu da se i ne govori (usp. Jehenson i Dunn 2010: 138 i 142).

Međutim, od pesimizma se ne živi i opravdan je jedino ako nije sam sebi cilj i ako ne odustane od ideala. Stoga Joshua Foa Dienstag smatra da je Don Quijoteov pesimizam prividan i da njegov tužni lik valja razumjeti kao "odavanje priznanja ljudskom stanju, pri čemu nije paraliziran, nego je, zapravo, njime potaknut” (Dienstag 1999: 88). Čak smatra da je glavni lik demijurg koji je zbog privrženosti ljudima (opet sličnost s Isusom!) napravio salto mortale:

Don Quijote završava ne tako što odustaje od ideala i junačkih priča, nego tako što preuređuje svijet oko sebe na vlastitu sliku. Prije ili kasnije svi drugi likovi dolaze u doticaj s Don Quijoteom ne pod svojim, nego pod njegovim uvjetima. To je slučaj i s njegovim umiranjem na odru, kada ga, nakon što dođe $\mathrm{k}$ sebi i odbaci svoje dotadašnje ponašanje, njegovi prijatelji mole da zadrži svoje ludilo i još jednom djeluje kao Don Quijote. (Dienstag 1999: 88-89)

\subsection{SUMNJA U NEPROTURJEČNU STVARNOST}

Tom pohvalom nesalomljivom duhu možemo se primaknuti središnjem okviru razumijevanja romana u ovom prilogu uz pomoć još nekih tumačenja. Tako Milan Vidaković podsjeća da su predložak romanu vjerojatno bila dva suprotstavljena lika starogrčke komedije, alazon i eiron. Prvi sebi laska i pravi se da može postići više nego što je postigao, zbog čega postaje predmetom izrugivanja. Drugi je lik vragolast izazivač koji prvog podbada i time čini ironijski odmak. Međutim:

[o]ba su smiješna, nijedan nije dosljedan, a njihova interakcija, zapravo, preoblikuje opažajni svijet u revidirani, logički zdraviji svijet, ali još uvijek otvoren prema istini. (Vidaković 2017: 169)

Nadalje ističe da je pitanje istine otvoreno i zaključuje da je dijalektički pristup najrelevantniji. Zahvaljujući povezanosti proturječnosti nijedan diskurs, idealistički ili materijalistički, ne smije se zapostaviti. Oba su ironijska, jer ishod interakcije uvijek ispada drukčijim od očekivanog, kao što je to u čitavoj povijesti. No, zbog toga se činjenični opis ne smije uzeti kao jedini 
meritoran. Na poslovično historiografsko (rankeovsko) pitanje "što se zaista dogodilo?" ne postoji samo jedan odgovor:

Dok bi stvarni sadržaj i kontekst tih pitanja mogli biti trivijalni, kada se sve uzme u obzir, način izražavanja i pitanja s početka poglavljâ Don Quijotea uokviruju priču sa smislom za istinu koja se oblikuje kroz sumnju u postojeće zapažanje stvarnosti. (Vidaković 2017: 177)

\subsection{DVA POLJA DRUŠTVENE SVIJESTI ${ }^{6}$}

Na sličnoj pretpostavci počiva socijalnokognitivistički pristup čiji su autori Serge Moscovici (1988; 2001) i Jean-Claude Abric (1995). Njihov ćemo pristup, koji naglašava da su društvene predodžbe nepomirljivo različite, ali u tom smislu i funkcionalne, preuzeti u nastavku analize Cervantesova romana. Oba autora bave se heterogenom, ali ipak povezanom, strukturom društvenih reprezentacija, što se može razumjeti i kao analitička inačica romaneskne ironije na račun samouvjerene istinoljubivosti. Prije svega, istina je misaona konstrukcija, djelomično izgrađena na osnovi empirijskih zapažanja, i nipošto se ne može ubrati kao jabuka u primordijalnom vrtu. Mitski početak spoznaje samo je početak. U nastavku procesa spoznaje sumnja u nepobitne istine postaje preduvjet znanstvenog mišljenja, ali opet ne i cilj.

To je odlika ljudskog mišljenja zbog koje Serge Moscovici ne vidi bitnu razliku između zdravorazumskih predodžbi o svijetu i paradigme, tog temeljnog Kuhnova koncepta znanstvene spoznaje. ${ }^{7}$ Obje su rezultat određenih konvencija, ne samo uma nego i srca. Prema Moscoviciju, "središnja jezgra" spoznaje nije racionalna u instrumentalističkom smislu, kao mjesto obrade informacija. Jezgra ima i emocionalnu vrijednost, a to je "konstruktivno nesvjesno". $\mathrm{Na}$ isti način prevrednuje značenje zdravog razuma i čak ga smatra glavnim ulazom u republiku znanosti:

Mi uzimamo samo mali odlomak našeg znanja i informacija iz naše međusobne interakcije i činjenica s kojima se susrećemo u svijetu. Najviše znanja ukupno dobivamo putem komunikacije koja utječe na naš način mišljenja

${ }^{6}$ Ova je tema razrađena na primjerima historiografskih sporova i nacionalne politike sjećanja u Europi, posebno u Hrvatskoj, u knjizi Rajska zajednica i društveni pakao - sociološka razmatranja (Katunarić 2013: 217-232).

${ }^{7}$ Istini za volju, Moscovici umjesto paradigma radije upotrebljava pojam themata zbog toga što se potonji pojavljuje u binarnim relacijama umjesto kao monistički koncept (usp. Jesuino 2008). 
i stvara nove sadržaje. Filozofkinja Hannah Arendt ispravno se poziva na zdrav razum kao bitan ljudski atribut. Bez njega ne možemo komunicirati, čak ni govoriti... misliti i raspravljati o istoj stvari. (Moscovici 1988: 215)

Isto se odnosi na moralna pravila ili norme. Don Quijote kao moralna vertikala nezamisliv je bez Sanchovih prigovora. Isto tako, znanost ne može proizvesti dovoljno razložne argumente ako ih ne uklopi u širi društveni svijet i ne pridonese održivosti svijeta života u cjelini.

Drugi autor, Jean-Claude Abric razlučuje dva, u (zdravoj) osnovi komplementarna, polja društvenih reprezentacija. Jedno je središnje (slično Moscovicijevoj "jezgri”), drugo je periferno, ali ne i manje važno. Ovdje sažimamo sadržaje Abricove dihotomije:

- Središnje polje daje prednost kolektivnim iskustvima, koja vrijede i kao povijesna. Periferno polje usredotočeno je na individualna iskustva i različitosti. Nadalje, središnje polje vodi računa o grupnoj homogenosti, posebno o stabilnosti i koherentnosti stavova. Stoga je otporno na promjene i neosjetljivo na neposredni kontekst.

- Periferno polje daje prednost heterogenosti, fleksibilnosti, pa i proturječju, uslijed čega stavovi evoluiraju, prije svega zbog osjetljivosti na neposredni kontekst. Međutim, periferno polje nije "teorijsko" jer ne uopćava iskustva i ne povezuje različitosti. Središnje polje odgovorno je za značajnost reprezentacije i određuje njezinu organizaciju, odnosno simbolički poredak, dok periferno polje dopušta prilagodbu na konkretnu stvarnost, diferencijaciju stavova $i$, što je najvažnije, štiti središnje polje (od autizma) (Abric 1995).

- U slučaju velikih društvenih potresa dolazi do raskidanja veza između dvaju polja, više međusobno ne korespondiraju i društvena reprezentacija zapada u stanje "kulturne shizofrenije" (usp. Shayegan 1997). ${ }^{8}$ Središnje polje više nema reference u iskustvu, a periferno je dezorganizirano, pa se iskustveno znanje ne može povezati ni s jednom središnjom idejom. U prvom slučaju središnje polje ponaša se kao "opsjednuti svjetonazor", poput fundamentalističkih ideologija, vjerskih i svjetovnih, a periferno preuzima funkcije središnjeg polja imponirajući kao "empirijska teorija”, koja je zapravo nemoguća (usp. Galtung 1989). Primjer pruža ideja "slobodnog tržišta", koja nigdje ne odgovara ponašanju stvarnih sudionika (na tržištu, kao i u društvu, nema jednakih).

${ }^{8}$ Ovo što slijedi proizlazi iz autorove primjene Abricova koncepta. 
U Cervantesovu romanu prvo je polje u kompetenciji hidalga, a drugo u kompetenciji sluge $-s$ time što nijedno ne sadrži cijelu istinu. Doduše, i Sancho ima svoje "središnje polje" koje nastaje, barem privremeno, zbrajanjem pokušaja i pogrešaka. U modernim uvjetima radnička klasa uči na isti način, nakon što je gotovo svugdje izgubila vodstvo, bilo sindikalno ili političko, samo da umakne prijetećoj bijedi i očaju. U tom će cilju za saveznika uzeti, takoreći, i vraga (totalitarizmi, lijevi i desni, jedno su se vrijeme temeljili na podršci radnika u zamjenu za siguran posao).

\subsection{KAPITALIZAM (UMJESTO) BUDUĆNOSTI}

Napokon, kako se u romanu isprepleću različiti slojevi vremena? S jedne strane, Cervantes ironizira mit kao bezvremensku kategoriju, nešto posve nepraktično. $S$ druge strane, ali ipak s trunkom ironije (inače bi Sancho kao lik bio suvišan), prihvaća ga kao uzor vrline u borbi za bolji svijet. $\mathrm{Na}$ taj način Don Quijote prolazi kroz sva tri vremena. Hod kroz vrijeme prate egzaltacija i mesijanski doživljaj vremena, što je posljedica širenja nesvjesnog. U sadržaju nesvjesnog vrijeme ne teče. To je stanje svojstveno i shizofreniji i velikom kolektivnom uzbuđenju koje se pojavljuje u usponima društvenih $\mathrm{i}$ političkih pokreta, kada se u trenutku čini da je sve moguće ("juriš na nebo"). ${ }^{9}$

Sancho pak živi u sadašnjosti. Njome raspolaže, ali na nezadovoljavajući način, pa i zato što mu prošlost ništa nije ostavila na dar, a budućnost mu je produžetak sadašnjosti. U dugom hodu uz gospodara puno se luta, a malo toga uživa. Za razliku od modernog čovjeka, Baudelaireova lunjalice koji, kao i Simmel osobno, otkriva besciljno kretanje kao oceanski prostor slobode (Simmel /1903/2001). Za Sancha, izvornog seljaka, društveni je svijet svugdje isti: pokvaren, bezobziran i opasan. Visoka načela, vjerska ili svjetovna, u koja se zaklinju vrhovi društva za ogromnu su većinu ljudi beskoristan ukras. To vide svi ljudi zdravog razuma, ali ne i njegov ludi gospodar koji u beznađu pronalazi viši smisao. Sancho pak život vidi kao niz slučajnosti koje malo kome donose sreću. A i sreća je pijanica:

Junačko srce, gospodaru, treba da jednako podnosi nesreću kao što se veseli sreći. Ja to sudim po sebi, jer dok sam namjesnikovao, bio sam veseo; sada, gdje sam perjanik, nisam žalostan. Ta čuo sam da je takozvana sreća nekakva

${ }^{9}$ To stanje Durkheim naziva kolektivnim vrenjem (effervescence collective) i opisuje kao ekstatičan doživljaj društva, koji je ujedno izvor religije. Društvena se stvarnost doživljava kao nešto nenadmašno i sveobuhvatno, što nadilazi individualnu svijest i egzistenciju. Doživljaj se osobito pojačava nazočnošću u gomili (Durkheim /1912/ 2008; usp. Katunarić 1996). 
pijana, hirovita žena, i još slijepa: ne vidi ona što radi, i ne zna koga ruši a koga diže. (Cervantes /1605/ 2019: 438)

Tim Sanchovim riječima Cervantes nagoviješta konačni udarac smislu društvene egzistencije, antidruštveni poredak, kapitalizam bez kapitalista, svijet posvemašnje nepravde koji nikoga ne pošteđuje, pa tako ni trenutne pobjednike u borbi: oni već sutra mogu propasti. To je ishod mahnitosti kapitala - "ne zna koga ruši a koga diže" - pogonjene tehničkim napretkom i neprestanom težnjom za stjecanjem profita. Tako je otvoren put k civilizaciji robota, kojoj je potrebno malo ljudi koji bi radili na poslovima održavanja. "Kapitalocen" smjenjuje antropocen. Preostali se ljudi, vjerojatno posljednji bogataši, kreću u skafanderima, poput Don Quijotea koji se klacka u trapavom oklopu, ovog puta pod višestruko jačim suncem i onečišćenim zrakom.

Uostalom, do takvog ishoda ne bi ni došlo da je bilo pravde, pa u neko doba više ne bi bilo ni proletarijata. U romanu je pravda prikazana u svojoj povijesnoj ružnoći, kao dokona i okrutna igrarija plemića na štetu Sancha. Oni su se za pravdu borili spektakularno, na viteškim turnirima. Na pravom bojištu pravdu zamjenjuje ratna sreća ili, riječima Platonova Trazimaha, 14 pravo jačega. Nemogućnost ostvarivanja pravde u svijetu nejednakosti oštroumno je objasnio Sancho obraćajući se okupljenim seljacima u ulozi arbitra na improviziranom viteškom turniru. Tvrdi da ne vrijedi boriti se jer se ishod dvoboja između nejednakih znade unaprijed. Da bi to zorno pokazao i pri tome izbjegao nasilje, sarkastično je ponudio nemoguće rješenje:

Braćo, nikako ne valja ono što traži debeljko, i nije ni nalik na pravdu, jer ako i jest istina, kako se veli, da uvrijeđeni odabire oružje, ipak on ne smije odabrati takvo oružje koje drugomu smeta i priječi ga te ne može pobijediti. Zato ja sudim da debeli izazivač mora sa sebe, bilo s koje strane tijela, saderati šest arroba mesa, kako mu je najzgodnije i najpriličnije; onda će se izjednačiti, izravnati sa onih pet arroba protivnikovih, pa će moći obadvojica najednako trčati. (Cervantes /1605/ 2019: 443)

"Vizija budućnosti" - misli se u ovom slučaju - sabrana je u dvije tragične pouke koje ćemo ponovo pokušati sociološki aktualizirati. Prva je da potrebama donje klase neće udovoljiti gornja klasa. Više od toga, suvremeni kapitalizam postaje nepogodan za život sve većem broju ljudi, uključujući i sve veći broj kapitalista koji se, primjenjujući ista pravila konkurencije, ne mogu domoći bogatstva. Druga je pouka da kapitalizam može postojati i bez svih manjih konkurenata na tržištu i da pravila za sve sudionike može podvesti pod monopole. Može li postojati i bez svih ljudi? To je još uvijek otvoreno pitanje. Iako se iz današnje perspektive kraj još ne nazire, trenut- 
ni procesi ocrtavaju napredovanje iste mahnitosti. Zaposleni u sve većem broju gube posao, a najveći je broj gubitnika među kronično nezaposlenima i siromašnima, koji gube posljednje rezerve strpljenja i kojima je razlika između života i smrti sve manja.

Samo je jedan posto ljudi, oni krajnje bogati, još osigurano protiv kuge beznađa. Oni su potomci establišmenta začetog u Europi još prije šesnaestog stoljeća. Ti su preci nesmetano, usporedno s rastom "slobodnog tržišta", nastavili živjeti kao monarsi, visoki kler i bogati trgovci razgranati u raznorodne špekulante pod zaštitom političke vlasti. S druge strane, viteza bez mane, čita se to na kraju romana i slično sluša na misama za njegova nebeskog pandana, ponovo zazivaju da nastavi svoju misiju, ovog puta protiv globalnog carstva čije se konture naziru na dvjema renesansnim slikama.

\section{DVA PRIMJERA ANTICIPACIJE IZ RENESANSNOG SLIKARSTVA}

Slijede prikazi dviju slika iz ranijeg renesansnog razdoblja. Kao i kasnorenesansni Cervantesov roman i one na svoj način najavljuju carstvo pijane sreće, kako ga je nazvao Sancho. Nova klasa u usponu, pokazuje Van Eyckova slika, rado sklapa ženidbene veze s pripadnicama vladajuće, feudalne klase. Potonju će u idućim stoljećima zamijeniti birokratska država koja bi službeno morala biti podjednako obzirna prema kapitalu i radnicima, što se pokazalo nerealnim. Druga slika, Leonardova, nagovješćuje raspad kršćanskog egalitarističkog pokreta u povojima na večeri na kojoj je najavljen rastanak između vođe pokreta i njegovih drugara. Zapravo, kršćanstvo će se odvojiti na anarhoidni i jedva opažljivi te na ustrojeni i napadno stršeći crkveni dio. Kao što Don Quijote nije mogao viteške ideale, uključujući zaštitu slabijih, ucijepiti u društveni život, tako ni kršćanski pobornici jednakosti i slobode, ta pučka inkarnacija "jedinstvene sjene" Don Quijotea i Sancha, nisu svoje ideale približili ogromnoj većini ljudi u kršćanskim društvima. Njima i dalje izgleda nemoguć silazak Kraljevstva Božjeg s ovu stranu groba. Tim masovnim pesimizmom obilno se hrane vladajuće oligarhije koje su prije šestotinjak godina sklopile povijesni sporazum, što ilustrira iduća slika. 


\subsection{RAĐANJE NOVOG SAVEZA}

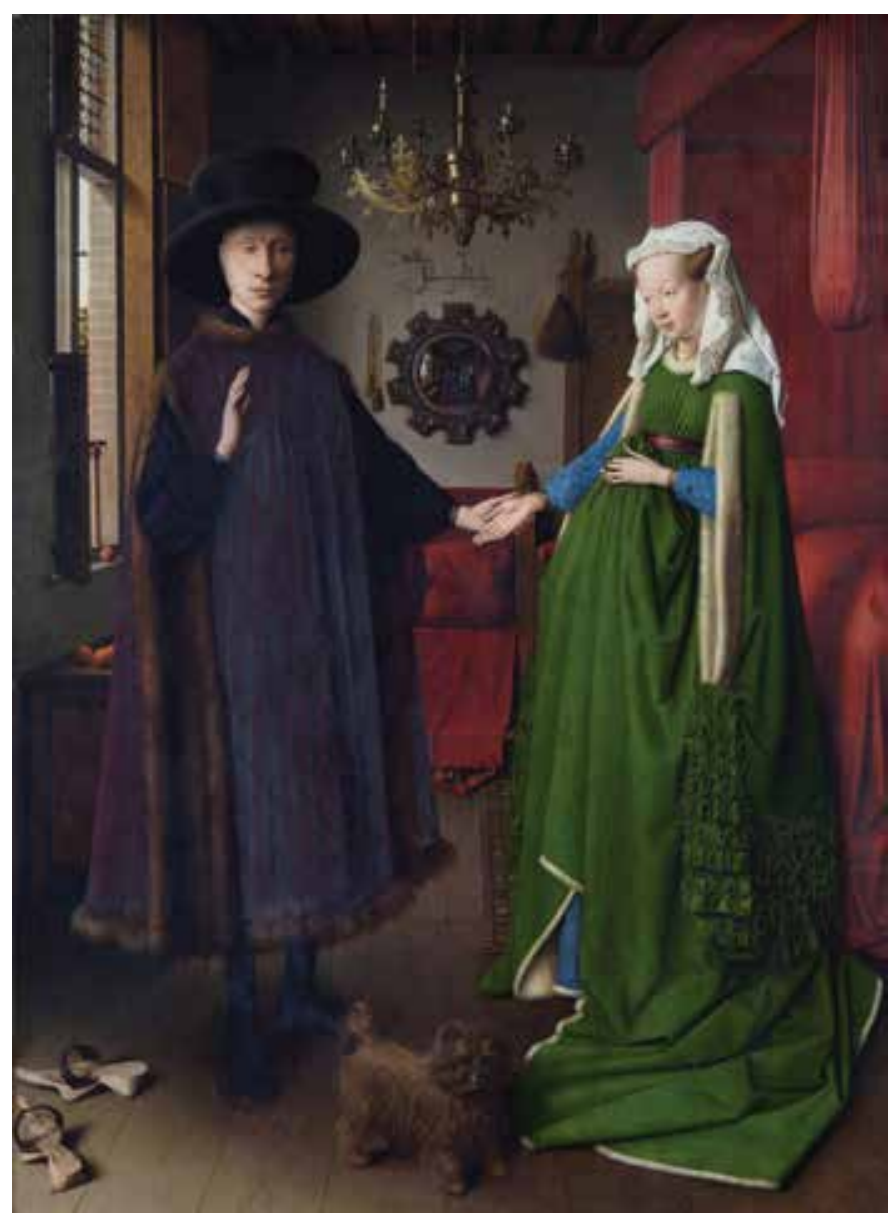

Jan van Eyck, Portret para Arnolfini, 1434.

Van Eyckova slika prikazuje ceremoniju tzv. "ljevorukog vjenčanja”, improvizaciju službenog vjenčanja, između kćeri talijanskog bankara (Giovanna Cenami) i trgovca (Giovanni Arnoflini) s političkom karijerom. Slika je služila kao dokument kojim se potvrđuje namjera sklapanja braka. ${ }^{10}$ Služ-

10 “Jan Van Eyck's Arnolfini ‘Wedding' Portrait”. U: SUNY Oneonta, The State University of New York. https://www.oneonta.edu/faculty/farberas/arth/arth214_folder/ van_eyck/arnolfini.html. Datum pristupa: 13. 11. 2019. 
beni brak sklopljen je 17 godina poslije. Prizor na slici na osobit način nagovješćuje porast anomije u društvima moderne epohe, koja je inducirana interesom nove klase u usponu za premošćivanjem svih barijera poslovnom uspjehu. Naravno, zanemarivanje tradicionalnih normi, uključujući one iz privatnog života i osobnih obaveza supružnika, te nestalnost prijateljskih veza nije nova pojava. No, u ovom se slučaju to čini zbog potrebe nove klase da atomizira društvo i svede ga na skup u osnovi usamljenih jedinki. Tržišnim centrifugiranjem društva olakšava se cirkulacija kapitala i drastično smanjuju ekonomski suvišni troškovi poput naknade za djecu, održavanja širih obitelji, javne zdravstvene zaštite ili obrazovanja o poreznom trošku. Osobito u gornjoj društvenoj klasi brak je najtradicionalnija institucija koja donosi i genetsko i materijalno nasljeđe barem dviju obitelji (orijentacija, u sociološkom smislu) (usp. Grandits i Heady 2004). Stoga je Arnolfini žarko želio imati sina kao imovinskog nasljednika. ${ }^{11}$

Poredak likova i predmeta na slici simbolički odražava prije svega rodnu dihotomiju unutar plemstva, kao i visoke buržoazije. Dom je za plemkinju "zlatni kavez". Ona uživa u materijalnom obilju, ali joj je sloboda kretanja, uključujući pojavljivanje u javnosti, ograničena. Svi predmeti na slici, u prvom redu zrcalo, omeđuju prostor za ženu. Vjerni pas čuva ženu koja se kune na vjernost od spavaće sobe do groba, a kipić Djevice Marije nadzire čednost budućih supružnika. Žena što bosa stoji na podu simbolizira svetost zemlje na kojoj je nastao dom, čime je "svakodnevni život podignut na razinu misterija". ${ }^{12}$

Ceremonija također zrcali društveni kontekst tradicije. ${ }^{13}$ Način odijevanja tipičan je za plemiće i imućne pripadnike srednje društvene klase koja nastoji hvatati korak s plemstvom u svakom pogledu. Ona prihvaća plemićke ceremonije, a istodobno juriša na političke položaje u rukama velikaša. $\mathrm{Na}$ dalje, naranča na slici simbolizira plodonosnost i želju za potomstvom te želju da se u "portfelj” novostečene moći uvrsti i položaj u službenoj vlasti.

${ }^{11}$ Brak je zbog neplodnosti jednog od supružnika ostao bez djece. Da nesreća bude veća, zbog jednog preljuba u međuvremenu morao je Arnolfini platiti visoku naknadu svojoj ljubavnici nakon što ju je napustio.

12 The Art Story. "Jan van Eyck" https://www.theartstory.org/artist/van-eyck-jan/ Datum pristupa: 30. 12. 2019.

${ }^{13}$ Oponašanje trbuha žene u drugom stanju uz pomoć jastuka na toj slici najavljuje očekivano potomstvo, no supružnici su živjeli bez djece i službeno se vjenčali tek 17 godina poslije (Seidel 1993: 129). Vidi također Jan Van Eyck's Arnolfini “Wedding” Portrait: https:// www.oneonta.edu/faculty/farberas/arth/arth214_folder/van_eyck/arnolfini.html) 
Za Arnolfinija politika ponajprije znači utjecaj na donošenje odluka koje idu u prilog trgovcima i drugim poslovnim ljudima.

Kao posljedica konstituiranja trostrukog saveza moći - ekonomskog, političkog i kulturnog, u biti vjerskog (o čemu više uskoro) - mjesta za ljubav, kao intimnu vezu isključivo u braku, sve je manje ili je već nestalo. Slično je sa sve bezobzirnijim odnosom spram biljaka i životinja. Monopolizirano bogatstvo, krajnje posesivno i okrenuto isključivo vlastitim interesima, osvaja svijet, koji, čini se, oduvijek postoji samo za njega.

Religija je posebno korisna u toj shemi moći s gledišta vladajućih skupina. $\mathrm{Na}$ slici je religijski element prisutan kao sveobuhvatan Duh Sveti kojeg simbolizira upaljena svijeća. No, važna institucija u nastanku kapitalizma, a još više u njegovu održavanju nije bila religija u cijelosti, nego Crkva. Ona, doduše, ne propovijeda bogaćenje, ali ga, za razliku od Isusa, tolerira. To je važan element svjetonazora o najboljem od svih svjetova, kojim se suzbija volja za otporom među potlačenima. Nepravde kapitalizma racionaliziraju se kao prirodne i neizbježne (usp. Stark 2005). Vjera u zagrobni život pak korisna je kao neutralizator samosvijesti donjih slojeva društva koji nisu uvijek neosjetljivi na mane kapitalističkog tržišta i općenito na nepravde. 18 Jedno od važnih uporišta za uvjerenje o nezamjenjivosti kapitalizma jest i selektivan prikaz alternativa kapitalizmu kao potpunih promašaja. Možemo se okladiti, baš na Pascalov način, da se u raju - bilo kao dobro zamišljenom društvu, ali ne i savršenom (samo su mrtvi nepogrešivi!), poput projekata utopijskih zajednica, ma kako kratkotrajnih, ili pak u dugotrajnim primitivnim zajednicama - više vodilo računa o svim pripadnicima nego u najrazvijenijim kapitalističkim društvima koja danas odbijaju imigrante kao dio svijeta koji tim društvima nikada nije pripadao (a čije su to bile kolonije?) niti će pripadati. Usporedno s poricanjem mogućnosti jednakosti te zajedničkog svijeta i (su)odgovornosti propada i moderna ideja čovjekova dostojanstva. Nju zamjenjuje ideja, u biti rasistička, da samo bogati mogu biti jednaki i slobodni. Isusova aluzija na račun bogatih i deve koja će prije proći kroz ušicu igle nego oni u raj nikada nije bila više obezvrijeđena.

Budućnost se na slici najprije najavljuje na mikrorazini. Kao alternativa braku ponuđeno je "partnerstvo". Taj termin ne donosi novu slobodu namjesto kanonske neraskidivosti braka niti je bolje rješenje u jezičnom i društvenom pogledu. Partnerstvo je u biti ugovor između menadžera u kojem nema mjesta za simpatije i ljubav, koje ne jamči ni tradicionalni brak. Ono što nastupa sve su krhkije veze, klonovi "slobodnog tržišta" na privatnoj razini.

Prenošenjem značenja slike na makrorazinu ukazuje se na početak mnogo trajnijeg saveza između kapitala i političke vlasti. U Europi je takav savez bio 
ustanovljen između dinastija i trgovačkih kapitalista. U 19. stoljeću zamijenjen je savezom između kapitala i (nacionalnih) država. Međutim, već u 15. stoljeću, kao što pokazuje Van Eyckova slika, kapital je izgledao kao zet koji ne želi nikome ništa dati. U nizu nepoželjnosti porezne obaveze spram države svakako su na prvom mjestu, s jednom važnom iznimkom. Ne samo već rani liberalizam i njegova dř̌ava noćobdija nego i sami kapitalisti radije će sufinancirati fizičku (vojnu i policijsku) zaštitu nego išta drugo iz javnog sektora. Ipak, preskočimo li nekoliko stoljeća, vidimo da se sigurnosna zaštita sve više privatizira i da već krajem 20. stoljeća niču paralelne policijske i vojne postrojbe, u nizu zemalja brojnije od službenih državnih, kojima je jedini cilj štititi imovinu i živote najbogatijih građana od presezanja razbojničkih bandi. Socijalna zaštita nema tu sreću, jer je kapitalist načelno smatra bacanjem novca u ruke birokracije i njezine "lijene", siromašne klijentele kojoj je nerad tobože životni cilj.

Osim što je socijalno neosjetljiv, kapital je i loš ljubavnik i muž. Zapravo, zazire od bilo kakve lojalnosti jer ona vodi, po njegovu prilično istinitom uvjerenju, u patrimonijalni odnos, tj. u korupciju i rentijerstvo, dočim pravi kapitalist mora biti, ako hoće postati uspješan poduzetnik, slobodan od tutorstva vlasti, ali i od gotovo svih zakonskih obaveza koje uključuju dodatno financiranje javnog sektora.

Naposljetku, na slici se može prepoznati isprepletanje triju vremena. Prošlost je poglavito utjelovljena u predmetima, od svijećnjaka do izuvenih cipela. Sadašnjica je prikazana namještajem i načinom odijevanja te, naravno, osobnom prisutnošću budućih supružnika. A budućnost - zapravo, dugo vrijeme koje poznajemo i čiji je veći dio za nas prošlost - obilježena je jednom diskretnom pojedinosti, ali od ključne važnosti. To je dodir ruku. Zaručnica je zaručnikovu ruku prihvatila blago i nesigurno, s mješavinom ponosa i straha, dok je njegova ruka ovlaš i nekako neiskreno polegla na njezinu. Možda je običaj takav, kao plesni razmak u renesansnim dances nobles, gdje pristojnost nalaže emocionalnu i tjelesnu suzdržanost. Pa ipak, ovdje približavanje izgleda nemoguće. $\mathrm{Na}$ jednoj strani jake emocije i nesigurnost, na drugoj proračunatost koja samo trasira interesnu vezu. Ali potonje nije dovoljno. Kao što znamo, spavaća soba priređena za mladi par nije bila jedina ložnica budućem supružniku. U jednoj drugoj dočekivala ga je privremena ljubavnica. U načelu je teško pretpostaviti kome je bio bliži, njoj ili supruzi. Slično se možemo pitati o odabranici američkog biznisa: je li to više Njemačka ili Saudijska Arabija? Ako prihvatimo da su poslovne veze po svojoj prirodi poligamne, a čini se da jesu - monogamna bi bilo kojem poslovnom partneru upropastila poduzetništvo - onda i staro i novo približavanje kapitalizma autoritarnim režimima postaje razumljivije. 
V. Ka tu n a ri ć, Društvene predodžbe, slojevi vremena i anticipacija u tri poznata umjet. djela (1-30)

"Umjetnost riječi" LXIV (2020) • 1-2 • Zagreb • siječanj - lipanj

\subsection{POSLJEDNJA VEČERA S DRUGARIMA}

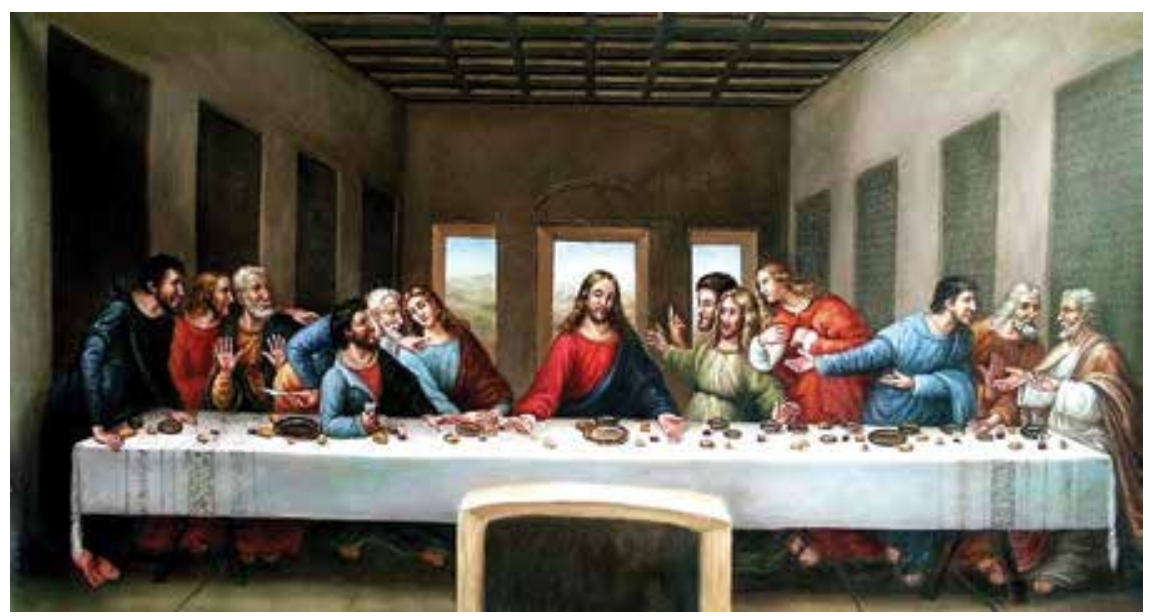

Leonardo da Vinci: Posljednja večera (1495-1498)

20 Iako neke povijesne analize upućuju na moguću autentičnost Posljednje večere (Humphreys 2011), Leonardova slika oslanja se samo na novozavjetnu pripovijest i nema, naravno, dokumentarnu vrijednost poput Van Eyckove slike. Tu samorazumljivu činjenicu uzimamo prije svega kao povod za razmatranje kategorije vremena u Bibliji, gdje se ukrštaju povijesno i mesijansko vrijeme. U Novom zavjetu, kao i u Don Quijoteu, ta se dva vremena medusobno ne isključuju. Prije bi se reklo da se međusobno dopunjuju i ispravljaju poput učenika koji se skupa pripremaju za ispit. Ključna je iterativna figura "u ona vremena" (in illo tempore). Ona se pojavljuje na početku niza poglavlja u Novom zavjetu i izgovara se na misama uz odlomke iz Biblije, liturgijski obred i svećenikovu propovijed. Taj je izraz ponajprije psihološki opravdan stoga što s biblijskih likova i tema, kao i misnog slavlja, simbolično skida "luđačku košulju". Prema tome, napomena da se veliki događaj o kojem je riječ zbio u davna vremena ima potencijalno terapeutski učinak na vjernike, ali ne i na one fanatične koji su svakog trenutka spremni obnoviti biblijski mitski trenutak, od uvjerenja da imaju Isusove stigme do uvjerenja da je upravo započela Apokalipsa. Težnju za ponavljanjem (pseudo)povijesnih činjenica i najave svršetka svijeta prema biblijskom tekstu posebno valja imati na umu kada je riječ o spornom očekivanju drugog Isusova dolaska, najavljenog u evanđeljima po Mateju i Ivanu (Otkrovenju), prema čemu je i Crkva opravdano skeptična. Zapravo, prvo upozorenje dolazi iz evanđelja, a riječ 
je o nadolasku lažnih proroka koji će se predstavljati kao Isus(i). Uostalom, kako te osobe prepoznati osim crkvenim ili psihijatrijskim pravorijekom?

U red uznemirujućih najava spada i Isusova najava učenicima na Posljednjoj večeri. Od svog učitelja čuli su uznemirujuću vijest da je izdan i još više uznemirujuću, zapravo zaprepašćujuću najavu svoje skorašnje smrti. Ako je to doista rekao, onda se radi o jedinoj istinskoj i činjenično potvrđenoj anticipaciji u Bibliji. Sve ostale najave, uključujući njegov skori povratak, ne potpadaju pod potvrđena predviđanja. Tako se jedino uz pomoć transpozicije "u ona vremena" teološka hermeneutika pomiruje s historiografskom konstatacijom. Povijest se doslovce ne ponavlja, ali zato često varira iste pojave ili osobe. Dapače, prema onoj Hegel-Heine-Marxovoj figuri, veliki događaji i osobe mogu se samo parodirati. Tome bi u novozavjetnoj perspektivi odgovarao dolazak lažnih proroka.

Vratimo se Leonardovoj slici. Na licima učenika dolazi do izražaja strah od budućnosti i s njim antinomijska misao: kako je moguće živjeti bez Boga koji je (navodno, s obzirom na to da je besmrtan) umro? Antinomija ugrožava razum koji počiva na evidenciji, a pothranjuje dogmatski um koji počiva na vjeri. Znanstvenik, dok je znanstvenik, ne može odustati od sumnje u nepobitne istine. Književnik kao Cervantes pak ima ironičan, ali u biti dvosmislen stav spram svog lika bez mane. No, barem na trenutke (književnik nije sistematski mislilac!), ne sumnja u Don Quijoteove dobre namjere i izvjesnu moralnu vertikalu koja se izdiže iznad vitezovih uzaludnih pokušaja. Nema razloga da se slično ne odnosimo spram antinomije koju je inducirao Isus, kao i spram njezina mogućeg razrješenja postupkom umjetnika, recimo estetskim obratom u odnosu između (ovaj put sna o) smrti i jave (u smislu neprekinute igre virtuoza vjere i junaštva). U pokušaju razumljivijeg objašnjenja vratimo se načas Cervantesovoj dvostrukoj hermeneutici, onoj umiranja i rehabilitacije glavnog junaka. Kao u nekom epilogu Cervantes prikazuje smrt čovjeka od principa koji postaje besmrtan upravo zbog svoje ljudske principijelnosti. Iz toga će, zbog etičke uzvišenosti i dubokog osjećaja za ponižene, poteći ontološki obrat, slobodnije rečeno materia rediviva. To je oblikovna materija umjetnika koju dijeli s muzama i koja tvori trajnu konstituciju svijeta zbog koje se on i ne može raspasti.

Doduše, svijet u kojem živimo nije još, kao ni čovjek, dovršeno djelo. Trag svijeta u nastajanju vodi kroz zonu sumraka. U njoj bogovi šute, a ljudi ne mogu međusobno razgovarati, dok se smrt smatra kaznom za grješan život, kao što je razumjela Racineova Fedra, samo zato što nije voljela stvarnog, nego idealiziranog Hipolita (usp. Goldmann /1963/ 2013: 683-685). 
Tu dolazimo do presudne točke, a to je nemogućnost da povučemo oštru razdjelnicu između sna i jave. To je zbog toga što san često tumačimo, što nije pogrešno ni prema Freudu ni prema nizu neurofiziologa, kao ispreturan odlomak jave. No pogrešno je što javu slično ne tumačimo kao klimav skup ostvarenih, ali duboko proturječnih, projekcija snova i potisnutih želja. Te iracionalne težnje mogu ostvariti ljudi dovoljno moćni, koji imaju sredstava da ih ostvare, ili još gore, da ih međusobno ukrste na ekonomskom ili ratnom bojnom polju. Zbog toga ispada da je društvena zbilja trajno proturječna i da je tako deformirana prepuna minusa i nagnuta nad bezdanom. Zbog nedostatka uravnoteženosti pretvara se u derivaciju paučinaste materije sna, koju mnogi sociolozi objašnjavaju kao projekciju moćnih društvenih skupina nametnutu nemoćnima i podređenima, poput preuske odjeće koja se često para pa ljudi hodaju u prnjama. Raj prvih očito je pakao za druge, uostalom kao centar i periferija u modernoj, kolonijalnoj ekonomiji.

Sa zaključkom da tkanje vremena može imati smisao kao i koprodukcija sna i jave vratimo se znakovima vremena na Leonardovoj slici. Premda je slikar ondašnju prošlost i svoju sadašnjost rekonstruirao na osnovi povijesnih činjenica i ponešto vlastitim zamišljanjem, unutrašnji prostor blizak je izgle22 du prostorija u lokalima 1. stoljeća nove ere. Isto je s odjećom i kosmatim ukrasima muških lica. Elementi budućnosti odnose se na način prehrane. $\mathrm{Na}$ to upućuje jedna studija o veličinama porcija i zdjela koje su prikazane na 52 najpoznatije slike pod naslovom Posljednja večera, uključujući Leonardovu, također temeljene na opisima iz evanđelja (Wansink i Wansink 2010). Ima i odstupanja: janjetina posluživana u vrijeme Pashe, dok se u Bibliji spominju samo kruh i vino. Prema istoj analizi proizlazi da "su se u posljednjih tisuću godina slikanja te biblijske scene porcije znatno povećale. Količina glavnog predjela općenito je narasla za nekih $70 \%$, količina kruha $23 \%$, a veličina zdjele $65 \%$. Usto meniju su dodane janjetina i svinjetina, dočim se na novijim slikama glavno jelo ne može razlučiti od ostalih jela" (Wansink i Wansink 2010: 943).

Sve obilniji obroci podsjećaju na trend enormnog porasta količine i asortimana predmeta u modernoj epohi, što je Georg Simmel označio kao "tragediju moderne kulture" koja proizlazi iz usporednog zanemarivanja "kulture osoba" (Simmel /1908/ 2001). Kultura pretovarena predmetima (omnia babentes, nibil posedentes), kaže, nastala je, logično, širenjem obrasca potrošnje više društvene klase na druge klase. Skromna ponuda na stolu s posluženim malim komadima kruha i vinom na Leonardovoj slici manje odražava kulturu srednje klase u 1. stoljeću n. e., sastavljene od obrtnika i trgovaca, a više supkulturu do tada manjeg društvenog pokreta. Prožeta je 
vrijednostima jednakosti, solidarnosti i empatije, uz doktrinarno preinačavanje židovskog monoteizma u figuru jedinstvenog Trojstva. Taj vjerski izraz pokreta, koji u biti zagovara komunistička načela, bio je tipičan dio političkog fenomena na periferiji carstva i, naravno, pokušaj afirmacije unutar monoteističkog narativa židovske religije. Iako Isus često ističe da nema namjeru narušavati vjeru predaka, odgovor klera bio je porazan. To je sudbina većine hereza, od vjerskih do svjetovno-političkih. Zbog istog je razloga Isus među dijelom Židova bio označen kao "novi Mojsije" (Humphreys 2011: 195-196).

Pogledajmo sada pobliže trostruku vremensku uzvojnicu na slici, koja uz sebe vezuje i imanentna i transcendentna značenja. Tako je prošlost prikazana i evolucijski, kroz geološku formaciju čiji se gorski lanac nazire kroz prozor dvorane. Bližu prošlost, kao i povijesnu sadašnjost, utjelovljuju umjetni predmeti i već spomenuto začešljavanje kose, premda upitno kao rašireni običaj. Zapravo, lice i tijelo u cjelini predstavljaju organska spremišta triju vremena, ${ }^{14}$ rastu i stare u isto vrijeme te završavaju ili produžuju život u budućnosti, koja i tradicionalno teološki i njuejdžovski nije samo linearna. Ona se račva s odvojkom u drugačiji svijet, poznat ne samo Joanne Rowling, autorici Harryja Pottera, nego i umjetnicima, u najmanju ruku još od renesanse, koji sliku života de-fragmentiraju. Dante je u Božanstvenoj komediji porazmjestio umrle među živima, posluživši se srednjovjekovnom klasifikacijskom shemom o dušama u paklu, čistilištu i raju, kojih nema u Novom zavjetu, ali se zato često spominje da je Isus tjelesno uskrsnuo.

Pokušajmo holističku vizuru - prošlo kao dio sadašnjeg i budućeg - nanovo razumjeti u široj perspektivi, koja je na trenutak nestala na Posljednjoj večeri zbog zatečenosti Isusovih drugara njegovom bombastičnom najavom. Slijed reakcija na slici izgleda kao zbirka minijaturnih portreta, svaki u svojoj vremenskoj kapsuli. Zajednički im je nazivnik šok, izuzev Isusa koji i dalje izgleda mirno i opušteno, kao da unaprijed zna da neće umrijeti, nego će

14 Što se tiče izvora, pretežno biblijskih, o načinu odijevanja Isusa i učenika, većina je toga još uvijek u sferi nagađanja. Do danas je utvrđeno, na primjer, svega nekoliko detalja koji se tiču Isusove tunike i sandala (o frizuri nijedan opis nema autentično potvrdu). Glavna je svrha tog u biti jednostavnog odijevanja da se izgledom podsjeća na siromahe (neki kritičari u idućim desetljećima tvrdili su da je takvo odijevanje prvih kršćana služilo samo jednoj svrsi: prošenju kao glavnom izvoru prihoda - usp. Taylor 2018). Posve je drukčije s obiljem značenja tijela u biblijskim, židovskim i kršćanskim tekstovima tog doba. Ponajviše židovski tekstovi ukazuju na širu dimenziju tijela u odnosu na uobičajeno poimanje i iskustvo tjelesnosti (usp. Hayter 2014). U tu kategoriju spadaju i Isusova iscjeljivanja bez dodira (usp. Harrocks 2014). Napokon, koncipiranje kategorije vremena u ovom prilogu, kao trostrukog spiralnog cirkuliranja (usporednih generacija bića u univerzumu), srodno je takvoj hermeneutici tijela. 
se nekamo skloniti, premda je u najtežim trenucima, razapet na križu, od silnih bolova ozbiljno posumnjao u nematerijalističku odvojenost duše od tijela, vapeći za pomoći Oca koji ga je u najgorem času napustio.

Prema daljnjoj priči Isus se uskoro, ali nakratko, pojavio među učenicima, ali u tjelesnom obliku i ne kao duh. Ispada da je smrt koja ga je bila zadesila jedan neizmjerno kratak i neopaziv trenutak prolaska kroz zvjezdana vrata, očima nevidljiva, iza kojih se stupa u neko drugo prostor-vrijeme. ${ }^{15}$ Vrata su, pretpostavlja se, pokretna i porazmještena u svim trima uzvojnicama prostor-vremena. Vremenski $\mathrm{DNK}^{16}$ sačinjava kozmički kontinuum biosfera, u kojem istodobno blizu i daleko (ovisno o osjećajnom razmaku, a ne o kilometrima ili svjetlosnim godinama) žive naše sestre i braća među ljudskim, čovjekolikim i drugim bićima. U toj isprepletenosti linearnost vremena nastaje i nestaje na mjestima na kojima se, poput rubova poprečnih ljestava unutar dvostruke uzvojnice DNK-a, spajaju vremenske uzvojnice. Uvjetno rečeno, mi smo ovdje i ondje gdje smo nekada bili, gdje sada jesmo i gdje ćemo biti ubuduće, vjerojatno opet, zašto ne?, kao suvremenici neke prošlosti. Opis se doima zbrkanim i nedovoljno shvatljivim jedino ako osjetila i racionalnu spoznaju, prema dugotrajnoj navici, strogo ograničimo na neki fragment cjelokupne zbilje. U suženoj perspektivi sve je tijesno, od vlastite kože i odjeće do prenapučenog planeta ili dokova na kojima od sto ljudi dva dobiju posao. U konačnici sve izgleda uzaludno i besmisleno, kao teško oboljelom Don Quijoteu i strašno izmučenom Isusu koji ne vidi nikakvo nebo.

Nakon renesanse društvo nije, naravno, postalo pravednije i ljepše. Ratovi su se nastavili i u epohi prosvjetiteljstva, najuspješniji suvereni dobili su titule Veliki zbog svojih osvajačkih podviga, a društvene nejednakosti i svijest ostale su u biti iste. Praktično ni nakon Francuske revolucije, sve do

${ }^{15}$ Ispričavam se kršćanskim vjernicima među čitateljima na njuejdžovskim analogijama. One pomažu da se smrt prispodobi kao tjelesna preobrazba i da se lakše iziđe na kraj s teškim nedoumicama oko pojma duše, što nije lako ni vjernicima, a kamoli nekome tko je više od pola stoljeća formiran u prosvjetiteljsko-znanstvenom svjetonazoru, a u starosti otkriva u njemu neke krupne nedostatke (usp. Katunarić 2020).

${ }^{16}$ Biološka, uzvojnica DNK-a dvostruka je i također neraskidiva kao elementarna struktura života. Vremenska uzvojnica, koju kao izraz upotrebljavam na vlastitu ruku, trostruka je i, dakako, simbolički izmještena, metaforična. Može se opisati kao vremenska strelica, dakle jednosmjerna, ali s osloncem na holističku misao može se zamisliti kao da se isprepleće s još dvije uzvojnice. Odgovarajući kršćanski simbol možda bi mogao biti Duh Sveti, zapravo ženska božanska osoba (u obliku Golubice /mira/, kako ju je, prema novozavjetnom zapisu, prepoznao Isus) i njezini ekvivalenti u drugim religijama i kulturama, od grčkog Feniksa i semitskih Ru/a/ha preko hinduske Advaite do japanskog Kamija. 
Treće republike, nije se vjerovalo u mogućnost ukidanja ili barem smanjivanja nejednakosti. Uz stara carstva snažno je raslo novo, kapitalističko, koje je u konačnici i svoje teritorije virtualiziralo. $U$ istom smjeru, nasuprot estetsko-umjetničkoj dimenziji, razvijala se analitička prirodoznanstvena spoznaja. ${ }^{17}$

Alternativni društveni proces u kršćanstvu, koji može u daljoj budućnosti preoblikovati svijet, možemo nazreti kao ozračje na Leonardovoj slici. Ono je do maloprije bilo opušteno, a potom uzburkano. $U$ tom komešanju ispražnjeno je veliko središte male družine. Na slici je upadljiv fizički razmak između Isusa i ostalih s obje strane stola. Družina tako od sada ima dvije jednake strane, postajući i acentrična i acefalna, ali ne i posve obezglavljena na dulju stazu. Glavnina kršćanskog svijeta formira se kao ogromna umrežena skupina jedinki, u osnovi anarhoidna. Sveukupno čini zajednicu koja svoju vezu s transcendentnim vođom ne održava isključivo putem Petrove crkve koja postupno, i to skupa sa šizmaticima i reformistima u idućim stoljećima, prerasta u monarhijsko-feudalnu ustanovu prianjajući uz svjetovna carstva i njihovu kolonijalnu politiku. Dotle je anarhoidni pokret nastavio živjeti u nekim svojim vremenima i formacijama nalik na jata i rojeve (kao dobroćudna, mirotvorna i visokointeligentna bića u Cameronovu Avataru). Posjećuju i mise, smještajući se u središnjem brodu i pokrajnjim lađama crkve, pažljivo slušajući što im se poručuje s oltara hijerarhijskog kršćanstva. Misa još traje, da parafraziramo Iljfa i Petrova, i još uvijek koegzistiraju dva različita dijela zajednice. $U$ onom brojnijem većinu čine žene, koje hijerarhija toliko prezire, a one to (još uvijek) strpljivo podnose.

Leonardova slika prikazuje, dakle, jedan od simboličkih začetaka dugotrajnog raspada ljudske zajednice. Ipak, kraj tog procesa ne mora izgledati poput apokaliptičkih ili marvelovskih scena ratovanja. Bio bi to najgori nastavak stare povijesti, zapravo njezin fizički završetak koji nijedan nauk o duši i zagrobnom životu ne može produžiti.

${ }^{17}$ Umjetnost prosvjetiteljstva, obnovivši vezu mita i sadašnjosti na vlastite načine, jednom slaveći barokno nebo plemstva, a u drugoj prilici neoklasičnu građansku isonomiju, učinila je daljnji korak k prikazivanju društva kao dijela kozmičkog poretka. Ali kakvog? $\mathrm{Na}$ to pitanje odgovorit će umjetnička avangarda s početka 20. stoljeća. Nova prirodoznanstvena spoznaja, čiji je teorijski izvor u prosvjetiteljstvu, a vrhunac Darwinova paradigma evolucije, prikazala je svijet kao vječnu borbu za prevlast nad resursima. Dotle je vječni mir, europska perspektiva koju je u epohi prosvjetiteljstva postulirao jedino Kant, a gotovo sve religije prebacile u zagrobni život, premješten u muzej iluzija nove (neoliberalne) tehnokracije. U kršćanskoj poruci koju ovdje razumijemo na svoj način, asocijacijom na Leonardovu sliku, životi u različitim dimenzijama međuovisni su: upropaštavanje jedne narušava i druge dvije uzvojnice. 
Nove večere, nazovimo ih "pretposljednjima", nisu siromaške kao ni Posljednja, nego s namjernom skromnošću okupljaju ljude među kojima se može i ne mora prepoznati prisutnost blisko-dalekog Isusa. Kako bilo, nije vjerojatno da će se on ponovo pojaviti kao karizmatski vođa. On je sada samo član acefalne formacije jednakih i slobodnih, možda primus inter pares, ali nezamisliv kako stoji visoko iznad vodoravne crte. Iz te društvene jezgre moguće je obnoviti svijet, čiji su pepeo i ruševine ipak samo ružan san, poput (Benjaminova) Anđela povijesti koji mora da je, zakoračivši u novu budućnost, slično doživio ruševnu prošlost. Takvo poništenje najgoreg u prošlosti posljedica je daljnjeg kretanja na vremenskoj uzvojnici. Vinovnici razaranja (bili) su svi oni progonjeni strahovima od konačnog uništenja tijela, materije koja beskonačno spaja sva vremena odlučujućim potezima majstora u radionicama velikih umjetnika svijeta života. Cervantes i Leonardo jedni su od njih.

\section{ZAKLJUČAK}

Ovaj je prilog imao dva cilja. Prvi je prepoznati društvene reprezentacije u Cervantesovu Don Quijoteu i način na koji u njima mit komunicira s vremenom. Drugi je cilj ocrtati trostruku vremensku uzvojnicu u strukturi umjetničkog djela. Radi što jasnijeg prikaza potonje teme, posebno anticipacije, koja je složenija od prethodne, analizi Cervantesova romana pridružene su analize dviju slika iz ranijeg razdoblja renesanse: Van Eyckova Portreta para Arnolfini i Leonardove Posljednje večere. $\mathrm{U}$ analizi anticipacijske dimenzije u sva tri djela prepoznati su elementi vizije nadolazeće ere kapitalizma. Usporedno s njegovim jačanjem bitno se smanjuju društvena solidarnost i pravednost na načelu jednakosti, a sloboda se pretvara u privilegij bogatih. Istodobno jačaju veze koje učvršćuju hijerarhiju društvenih klasa, a posebno interese najgornje klase. Naposljetku, otvara se pitanje koje je samo ovlaš dotaknuto u ovom članku: je li epoha prosvjetiteljstva u čijim tekovinama još živimo, koja slijedi nakon renesanse, ${ }^{18}$ svojim osloncem na pozitivnu znanost i primijenjena ili tehnološki iskoristiva znanja, čiji se najsofisticiraniji proizvodi ugrađuju u vojnoindustrijski kompleks, čime je izokrenut odnos

${ }^{18}$ Renesansa je u potrazi za odgovorima na granična pitanja vezana za mitske i religijsko-magijske sadržaje, kao što je, na primjer, komunikacija s pokojnim ocem-kraljem na početku Shakespeareova Hamleta. 
V. Katun a ri ć, Društvene predodžbe, slojevi vremena i anticipacija u tri poznata umjet. djela (1-30

"Umjetnost riječi" LXIV (2020) • 1-2 • Zagreb • siječanj - lipanj

između uzvišenog i banalnog, simbolički između Don Quijotea i Sancha, pogodovala kolosalnom rastu kapitalizma i njegovim pogubnim posljedicama za svijet u kojem živimo? ${ }^{19}$

\section{LITERATURA}

Abric, Jean-Claude. 1995. "L'organisation interne des representations sociales". U: Structures et transformations des représentations sociales. Ur. Christian Guimelli. Paris: Delachaux et Niestlé: 73-84.

Benjamin, Walter. 1974. "On the Concept of History". U: Gesammelte Schriften I: 2. Frankfurt am Main: Suhrkamp Verlag. Prev. Dennis Redmond.

https://www.marxists.org/reference/archive/benjamin/1940/history.htm 22. siječnja 2020.

Blake, William. (1794) 2004. Poems. Publisher: PoemHunter.Com - The World's Poetry Archive. https://www.poemhunter.com/william-blake. 19. siječnja 2020.

Cervantes, Miguel de Saavedra. (1605) 2019. Bistri vitez Don Quijote od Manche. (Dio prvi). Preveli Iso Velikanović i Josip Tabak. docplayer.es/64046717-Bistri-vitez-don-quijote-od-manche.html. 19. siječnja 2020.

Cervantes, Miguel de Saavedra. (1605) 2019. Bistri vitez Don Quijote od Manche. (Dio drugi). Preveli Iso Velikanović i Josip Tabak. docplayer.es/64046717-Bistri-vitez-don-quijote-od-manche.html. 19. siječnja 2019.

Croce, Benedetto. (1902) 2013. Aesthetic as Science of Expression and General Linguistic. https://librivox.org/aesthetic-as-science-of-expression-and-general-linguistic-by-benedetto-croce-2/. 20. prosinca 2019.

Dienstag, Joshua Foa. 1999. "The pessimistic spirit”. U: Philosophy \& Social Criticism 25, 1: 71-95.

Durkheim, Emile. (1912) 2008. Elementarni oblici religijskog života: totemisticki sustav u Australiji. Prev. Aljoša Mimica. Zagreb: Naklada Jesenski i Turk - Hrvatsko sociološko društvo.

Galtung, Johan. 1989. "Theory formation in social science: a plea for pluralism”. U: Comparative Methodology. Ur. Elisabeth Øyen. London: Sage.

Goldmann, Lucien. (1963) 2013. The Hidden God. A Study of Tragic Vision in the Pensees of Pascal and the Tragedies of Racine. Prev. Phillip Thody. Routledge \& Keagan Paul.

Grandits, Hannes i Patrick Heady (ur.). 2003. Distinct Inheritances: Property, Family and Community in a Changing Europe. Münster: Lit Verlag - Max-Planck-Institut für ethnologische Forschung.

Gutierrez, Gonzalo. 2013. While the future awaits: essays on anticipation. Duchamp and contemporary Cuban art.

https://www.researchgate.net/...whilethefutureawaitsessaysonantici. 19. prosinca 2019.

Harrocks, Rebecca. 2014. "Jesus' Gentile Healings: The Absence of Bodily Contact and requirement of Faith". U: The Body in Biblical, Christian and Fewish Texts. Ur. Joan E. Taylor. London/New York: Bloomsbury T\&T Clark: 58-82.

\footnotetext{
${ }^{19}$ Vidi opširnije o tome u Katunarić 2020.
} 
V. Ka tu n a ri ć, Društvene predodžbe, slojevi vremena i anticipacija u tri poznata umjet. djela (1-30)

"Umjetnost riječi" LXIV (2020) • 1-2 • Zagreb • siječanj - lipanj

Hayter, Daniel W. 2014. “'How Are the Dead Raised?': The Bodily Nature of Resurrection in Second Temple Jewish Texts". U: The Body in Biblical, Christian and fewish Texts. Ur. Joan E. Taylor. London/New York: Bloomsbury T\&T Clark: 123-143.

Humphreys, Colin, J. 2011. The Mystery of the Last Supper: Reconstructing the Final Days of Jesus. Cambridge University Press.

Jan Van Eyck's Arnolfini "Wedding” Portrait

https://www.oneonta.edu/faculty/farberas/arth/arth214_folder/van_eyck/arnolfini.html

Jehenson, Myriam Yvonne i Peter N. Dunn. 2010. "Discoursive Hybridity: Don Quijote's and Sancho Panza's Utopias”. U: Miguel De Cervantes' Don Quixote. Ur. Harold Bloom. Infobase Publishing: 127-144.

Jesuino, Jorge Correia. 2008. "Linking Science to Common Sense". U: Fournal for the Theory of Social Behaviour 38, 4: 393-409.

Katunarić, Vjeran 1994. "Masovno ludilo: noviji pristupi i njihove implikacije". U: Društvena istraživanja 3, 6: 651-670.

Katunarić, Vjeran. 2001. "Predgovor urednika”. U: George Simmel. Kontrapunkti kulture. Ur. Vjeran Katunarić. Zagreb: Naklada Jesenski i Turk - Hrvatsko sociološko društvo: 1-22.

Katunarić, Vjeran. 2020. "Desentized genius: the actuality of Dialectic of Enlightenment". U: Berlin Fournal of Critical Theory 4, 1: 5-36.

Marchante-Aragón, Lucas A. 2016. “Don Quixote's Ana Félix: The Virile Morisca Maiden and the Crisis of Imperial Masculinity". U: Hispanofila 176: 3-18.

28 Marx, Karl i Friedrich Engels. (1848) 2008. Manifest Komunističke partije. Prijevod Moša Pijade. Redakcija prijevoda Boris Buden. London/Zagreb. Ekonomija/Economics 15.3, 565-596. www.rifin.com

Marzhan, Rebekah. 2012. "Don Quixote and Jesus Christ: The suffering 'Idealists' of Modern Religion". U: Oceánide 4ł. www.oalib.com > paper

Merleau-Ponty, Maurice. 1968. The Visible and the Invisible. Prev. Alphonso Lingis. Evanston: Northwestern University Press.

Moscovici, Serge. 1988. "Notes towards a description of Social Representations". U: European Fournal of Social Psychology 18, 3 (July): 211-225.

Moscovici, Serge. 2001. Social Representations. Explorations in Social Psychology. New York: New York University Press.

Shayegan, Daryush. 2007. Cultural Schizophrenia: Islamic Societies Confronting the West. Syracuse University Press.

Seidel, Linda. 1993. Jan Van Eyck's Arnolfini Portrait: Stories of an Icon. Cambridge University Press.

Simmel, Georg. (1908) 2001. "Pojam i tragedija kulture". U: George Simmel. Kontrapunkti kulture. Ur. Vjeran Katunarić. Zagreb: Naklada Jesenski i Turk - Hrvatsko sociološko društvo: 23-50.

Simmel, Georg. (1903) 2001. "Velegradovi i duhovni život". U: George Simmel. Kontrapunkti kulture. Ur. Vjeran Katunarić. Zagreb: Naklada Jesenski i Turk - Hrvatsko sociološko društvo: 137-151.

Simmel, Georg. (1896) 2001. "Sociologijska estetika". U: George Simmel. Kontrapunkti kulture. Ur. Vjeran Katunarić. Zagreb: Naklada Jesenski i Turk - Hrvatsko sociološko društvo: 207-222. 
V. Katunarić, Društvene predodžbe, slojevi vremena i anticipacija u tri poznata umjet. djela (1-30

"Umjetnost riječi" LXIV (2020) • 1-2 • Zagreb • siječanj - lipanj

Simmel, Georg. 1901. "Stefan George. Eine kunstphilosophische Studie." U: Neue Deutsche Rundschau, 13. Jg., Heft 2 vom Feb. 1901, S. 207-215 (Berlin). https:// www.uni-due.de/lyriktheorie/texte/1901_simmel.html\#text)

Stark, Rodney. 2005. The Victory of Reason: How Christianity Led to Freedom, Capitalism, and Western Success. New York: Random House.

Taylor, Joan E. 2018. What Did Jesus Look Like? London/New York: Bloomsbury T\&T Clark.

The Art Story. "Jan van Eyck". https://www.theartstory.org/artist/van-eyck-jan/. 30. prosinca 2019.

Vargas Llosa, Mario. 2010. "A Novel for the Twenty-first Century". U: Miguel De Cervantes' Don Quixote. Ur. Harold Bloom. Infobase Publishing: 57-68.

Vidaković, Milan. 2017. "Irony Called into Question: Don Quixote's Alazon and Eiron". $\mathrm{U}:$ Papers on Language \& Literature 53, 2 (Spring): 166-190.

Wansink, Brian i Craig Wansink. 2010. "The largest Last Supper: depictions of food portions and plate size increased over the millennium". U: International fournal of Obesity 34, 5: 943-944.

Wiskus, Jessica. 2013. The Rhythm of Thought. Art, Literature, and Music after Merleau-Ponty. Chicago/London: The University of Chicago Press.

\section{Abstract}

\section{SOCIAL REPRESENTATIONS, TEMPORAL LAYERS AND ANTICIPATION IN THREE FAMOUS WORKS OF ART}

The paper starts with the conceptual/theoretical approaches to social representations, structures of time, and vision of the future (anticipation) in three works of art. Don Quixote by Miguel Cervantes is a model example for illustrating the stated approaches. The concept of social representations (Durkheim, Moscovici, Abric) can be illustrated by the protagonist in Cervantes' novel. Cervantes' implicit vision of the future, except a turnover at the end of the novel, is closer to Sancho's realism and pessimism than Don Quixote's idealism and optimism. Such a shift in the central field of social awareness has a double impact on the way of understanding social reality. First, complementarity between the central (visionary) and the peripheral area (of everyday experience) of social consciousness is reduced, and contradiction is enhanced. Second, this contradiction exacerbates reversal in the relation between the sublime and banal for the sake of the unfettered market. The conclusive remarks offer a new research field concerning the impact of the subsequent epoch of the Enlightenment on the levelling of the values in the name of both the scientific disenchantments of the world and the expansion of the centrifugal forces of the marketplace. The concept of anticipation is further discussed with two works of art from the Renaissance: Jan van Eyck's "Portrait of Arnolfini” and Leonardo da Vinci's “The Last Supper". Both works anticipate the coming of 
capitalism. The first painting points out the function of marriage as the institution of inheritance and accumulation of private property, as a part of the new alliance of power between the new middle class and the old upper (feudal) class. In the second painting, Jesus' announcement of his death results in the emptying of the moral centre-stage of Christianity. This moment opens the space for the penetration and eventual hegemony of capitalism in society. The morality of the Church is rather provisory and fluctuates between two contrasts: One is the illusion of the return of Jesus, and the other is the rise of the new secular power, the totalitarian capitalism, which does not permit any alternative, as if wanting to replace the "only one God".

Keywords: works of art, Don Quixote, social representations, central and peripheral field, time layers, anticipation 